\title{
REDUNDANT VARIABLES AND THE QUALITY OF MANAGEMENT ZONES
}

Doi:http://dx.doi.org/10.1590/1809-4430-Eng.Agric.v36n 1p78-93/2016

\section{RICARDO SOBJAK ${ }^{1}$, EDUARDO G. DE SOUZA ${ }^{2}$, CLAUDIO L. BAZZI ${ }^{3}$, MIGUEL A. URIBE-OPAZO ${ }^{4}$, NELSON M. BETZEK ${ }^{5}$}

\begin{abstract}
Precision agriculture (PA) allows farmers to identify and address variations in an agriculture field. Management zones (MZs) make PA more feasible and economical. The most important method for defining MZs is a fuzzy C-means algorithm, but selecting the variable for use as the input layer in the fuzzy process is problematic. BAZZI et al. (2013) used Moran's bivariate spatial autocorrelation statistic to identify variables that are spatially correlated with yield while employing spatial autocorrelation. BAZZI et al. (2013) proposed that all redundant variables be eliminated and that the remaining variables would be considered appropriate on the $\mathrm{MZ}$ generation process. Thus, the objective of this work, a study case, was to test the hypothesis that redundant variables can harm the MZ delineation process. BAZZI This work was conducted in a 19.6-ha commercial field, and $15 \mathrm{MZ}$ designs were generated by a fuzzy $\mathrm{C}$-means algorithm and divided into two to five classes. Each design used a different composition of variables, including copper, silt, clay, and altitude. Some combinations of these variables produced superior MZs. None of the variable combinations produced statistically better performance that the MZ generated with no redundant variables. Thus, the other redundant variables can be discredited. The design with all variables did not provide a greater separation and organization of data among MZ classes and was not recommended.
\end{abstract}

KEYWORDS: precision agriculture, spatial correlation, relative efficiency.

\section{VARIÁVEIS REDUNDANTES E A QUALID ADE DE ZONAS DE MANEJO}

RESUMO: A agricultura de precisão proporciona aos agricultores identificar e tratar de forma adequada as variações encontradas na área agrícola. As zonas de manejo (ZMs) permitem a implantação da agricultura de precisão de forma viável e relativamente mais econômica. A forma mais importante para definir ZMs é usando o algoritmo fuzzy C-means. Um problema consiste em como selecionar a variável a ser usada como layer de entrada no processo fuzzy. Assim, o objetivo deste trabalho, foi testar a hipótese de que variáveis redundates podem prejudicar o processo de delineamento de ZMs. Este trabalho foi desenvolvido em uma área de 19,6 ha e 15 agrupamentos de ZMs foram gerados por meio do o algoritmo fuzzy C-means, dividindo-se em duas a cinco classes. Cada agrupamento usou uma composição diferente de variáveis, que são os atributos cobre, silte, argila, e altitude. Foi encontrado que algumas combinações dessas variáveis produziu melhores ZMs. Nenhuma combinação de variáveis produziu desempenho estatisticamente melhor que a ZM gerada apenas com as variáveis não redundantes. Assim, as variáveis redundantes podem ser descartadas. O agrupamento com todas as variáveis não forneceu maior separação e organização dos dados entre as classes de ZM, não sendo recomendado.

PALAVRAS-CHAVE: agricultura de precisão, correlação espacial, eficiência relativa.

\footnotetext{
${ }^{1}$ Technologist in Data Processing, MSc in Agricultural Engineering, Computer Science Departament, Technological Federal University of Paraná, Av. Brasil, 4232, 85884-000, Medianeira, Paraná, Brazil, ricardosobjak@utfpr.edu.br

${ }^{2}$ Mechanical En gineer, PhD in Mechanical En gineering, PGEAGRI, UNIOESTE - Western Paraná State University, Productivity researcher of the CNPq. Rua Universitária, 2069. 85819-110. Cascavel, Paraná. Brazil, Eduardo.souza@ unioeste.br

${ }^{3}$ Technologist in Data Processing, PhD in Agricultural Engineering, Computer Science Departament, Technological Federal University of Paraná, Av. Brasil, 4232. 85884-000. Medianeira, Paraná. Brazil.

${ }^{4}$ Statistician, PhD in Statistics, Associated Professor, PGEAGRI, UNIOESTE - Western Paraná State University, Productivity researcher of the CNPq. Rua Universitária, 2069. 85819-110. Cascavel, Paraná. Brazil.

${ }^{5}$ Technologist in Data Processing, MSc in Agricultural Engineering, Computer Science Departament, Technological Federal University of Paraná, Av. Brasil, 4232. 85884-000. Medianeira, Paraná. Brazil. 


\section{INTRODUCTION}

The spatial and temporal variability of soil attributes and weather conditions may affect soybean development (GUASTAFERRO et al., 2010). The spatial and temporal variations that affect production must be elucidated so that these variations can be considered in crop management. Precision agriculture (PA) is an agricultural management system based on spatial variations of soil and crops attributes in production fields. PA aims to optimize profitability, sustainability and environmental protection (MOLIN et al., 2010) by employing localized application of inputs to an agricultural field. Among studies seeking to evaluate the economic viability of PA, those that incorporate management zones (MZs) aim to analyze and provide recommendations on the division of production areas into smaller MZs that are treated differently. Such practices allow farmers to use the same systems used in conventional agriculture during crop management (RODRIGUES JUNIOR et al., 2011). According to ROUDIER et al. (2011), MZs simplify the representation of spatial variability in a cropping field. The management of such small and uniform regions (MZs) is considered by MOLIN \& CASTRO (2008) one of the most challenging stages of PA.

Clustering methods are highly recommended for defining MZs (YAN et al., 2007; ILIADIS et al., 2010) and include the use of several attributes such as electrical conductivity, elevation, slope and soil texture, and nitrogen alone and in combination. Although any attribute may be related to crop yield, for DOERGE (2000), the ideal attribute is the correlation of predictable spatial information sources with yield. Clustering techniques for MZ generation include algorithms such as K-Means and Fuzzy C-Means (ILIADIS et al., 2010; VALENTE et al., 2012 and LI et al., 2013), which offer good results (VITHARANAet al., 2008; MORARI et al., 2009; MORAL et al., 2010; RODRIGUES JUNIOR et al., 2011; DAVATGAR et al., 2012; KWEON, 2012; BANSOD \& PANDEY, 2013), which permit the automatic division of the studied field. In this approach, different data sources that are related to crop development factors can be used to generate MZs.

The most used unsupervised clustering algorithm is Fuzzy C-means (also known as Fuzzy Kmeans). This algorithm uses an iterative process to recalculate the cluster means and assign data points to clusters. Fuzzy C-means uses a weighting exponent to control the degree to which membership sharing occurs between classes (BEZDEK, 1981). This approach is important because it allows individuals to exhibit partial membership in each of a number of sets, thus enabling the study of continuous variability in natural phenomena (BURROUGH, 1989). Before a data cluster can be formed, an appropriate measure of similarity must be established, which is typically the normalized distance from an observation to the cluster mean in attribute space (TOU \& GONZALEZ, 1974; JOHNSON, 1998). One of the more frequently used measures of similarity is the Euclidean distance, which gives equal weight to all measured variables and is sensitive to correlated variables (BEZDEK, 1981). Geometrically, the Euclidean distance generates clusters with a spherical shape, which rarely occurs in a real soil system (ODEH et al., 1992).

The influence of a variable (attribute) on yield must be measured before it can be selected and considered in the $\mathrm{MZ}$ determination process. The criteria to select a variable must consider its required spatial autocorrelation and the spatial correlation of the variable with yield. BAZZI et al. (2013) used Moran's bivariate spatial autocorrelation statistic to propose a procedure for selecting variables as input data for the Fuzzy C-Means algorithm.

Thus, this trial aims to test the hypothesis that redundant variables can harm the MZ delineation process.

\section{MATERIAL AND METHODS}

This work was conducted in a 19.6-ha commercial field from April 2009 to January 2011. The experimental field was cropped with soybean. The field is located in southern Brazil, western Paraná, municipality of Cascavel (Figure 1). Its geographical coordinates are 24⒌'19" S and $53^{\circ} 33^{\prime} 59^{\prime \prime} \mathrm{W}$, with an average altitude above sea level of $706 \mathrm{~m}$. 
Soil samples were collected at 55 different sites in the field $\left(2.8\right.$ points ha ${ }^{-1}$, Figure 1$)$ to obtain data on soil resistance to penetration (SRP) and soil chemical properties at a depth of 0 to $0.20 \mathrm{~m}$. SRP was measured with a penetrometer Falker SoloTrack PLG1020. The sampling elements of soil texture were collected from 45 of the 55 sites. Soil sampling was conducted with the aid of an auger at a depth of 0-0.2 $\mathrm{m}$, and for each of the sampling points, eight sub-samples were collected within a radius of $3 \mathrm{~m}$ from the point determined by the sampling grid (adapted from WOLLENHAUPT et al., 1994).

The quantitative values obtained were potential hydrogen $(\mathrm{pH})$, phosphorus $(\mathrm{P})$, potassium $(\mathrm{K})$, copper $(\mathrm{Cu})$, zinc $(\mathrm{Zn})$, iron $(\mathrm{Fe})$, manganese $(\mathrm{Mn})$, calcium $(\mathrm{Ca})$, magnesium $(\mathrm{Mg})$, carbon (C), aluminum $(\mathrm{Al})$ and the contents of sand, clay and silt. The soybean yield data were collected from 130 sampling points manually collected and corrected at $12 \%$ water content. Each sample point was represented by the total mass collected on two lines in a path of one meter and, because the spacing was $0.45 \mathrm{~m}$, each sample point was represented by an area of approximately $0.9 \mathrm{~m}^{2}$.
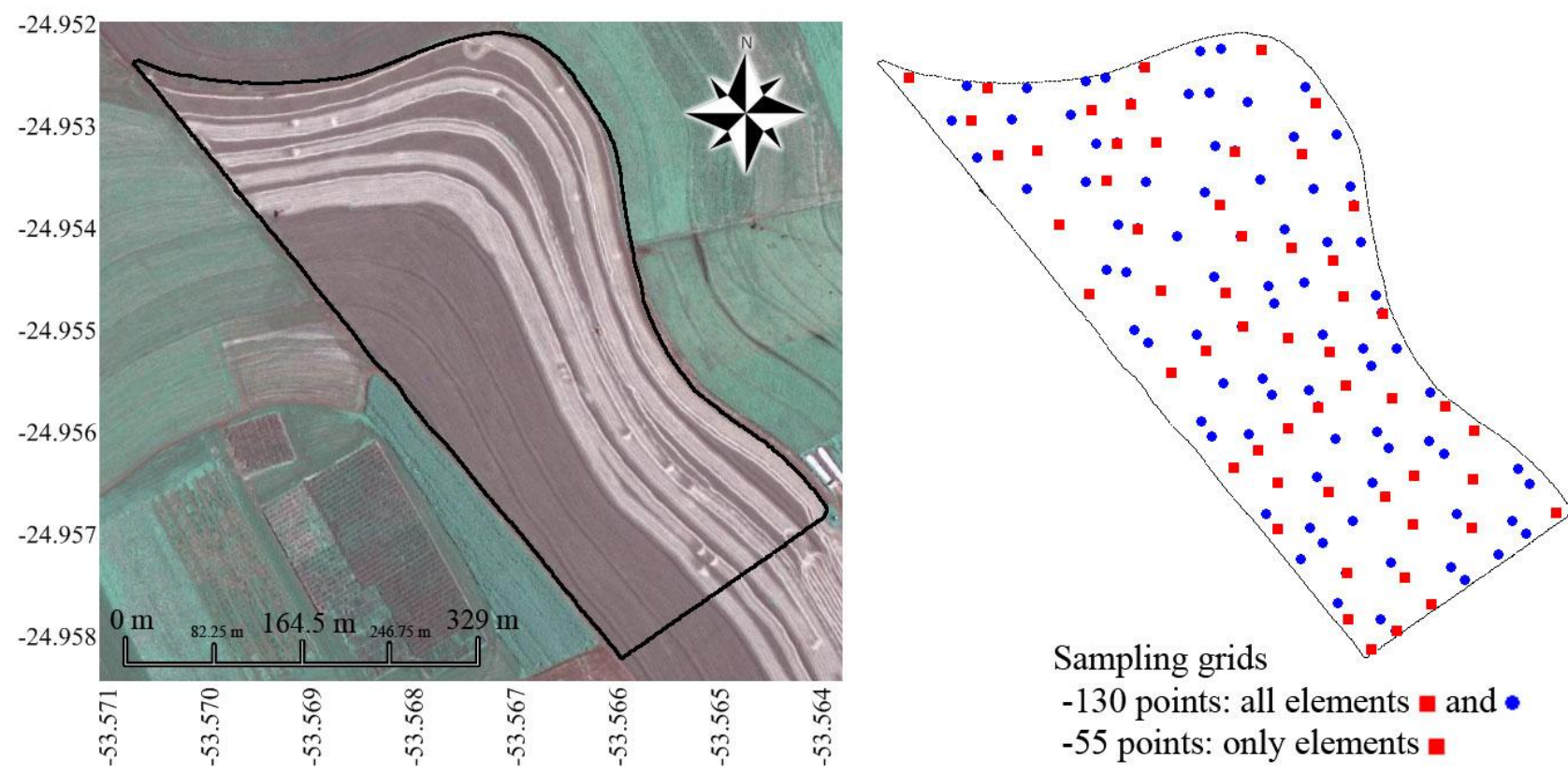

Source: Adapted from GOOGLE EARTH (2009).

FIGURE 1. Experimental field and its sampling grid. All red and blue elements represent the 130-point grid; red-only elements represent the 55-point grid. Municipality of Cascavel, Paraná, Brazil.

Based on statistical descriptive analysis of the data, measures of central tendency (mean and median) and measures of dispersion (variance, standard deviation and coefficient of variation) were determined. To evaluate the data normality at 5\% probability, Anderson-Darling and KolmogorovSmirnov tests were performed, and those with normality for at least one of the tests were considered normal. To evaluate the correlation among chemical and physical properties of soil, topography and soybean yield, Moran's bivariate spatial autocorrelation statistic $I_{Y Z}$ (BONHAM et al., 1995), shown in [eq. (1), was applied. The hypothesis of no spatial autocorrelation was tested at the 5\% significance level.

$$
I_{Y Z}=\frac{\sum_{i=1}^{n} \sum_{j=1}^{n} w_{i j} \cdot Y_{i} \cdot Z_{j}}{S \sqrt{m_{Y}^{2} \cdot m_{Z}^{2}}}
$$


where,

$w_{i j}$ is an element of matrix $W$ of spatial association, which measures the association among elements at positions $i$ and $j$ (calculated by $w_{i j}=\left(1 / 1+D_{i j}\right)$ ) so that $D_{i j}$ is the distance between $i$ and $j$ points;

$Y_{i}$ - is the value of variable $Y$ transformed at point $i(i=1, \ldots, n)$ to obtain a zero mean, according to $Y_{i}=\left(Y_{i}-\bar{Y}\right)$, where $\bar{Y}$ is the sampling mean of $Y$ variable;

$Z_{j}$ is the value of $Z$ variable transformed at point $j(j=1, \ldots, n)$ to obtain a zero mean from the formula $Z_{j}=\left(Z_{j}-\bar{Z}\right)$, where $\bar{Z}$ is the sample mean of $Z$ variable;

$S$ is the sum of all degrees of spatial association, obtained from elements $w_{i j}$ for $i \neq j$;

$m_{Y}^{2}$ is the sample variance of variable $Y_{i}$, and

$m_{Z}^{2}$ is the sample variance of variable $Z_{j}$.

The spatial correlation matrix was generated for the analyzed variables; in the matrix, the autocorrelation values of each variable are the elements on the main diagonal, whereas the offdiagonal elements are the cross-correlations among variables. The coefficients were tested at the $1 \%$ and 5\% significance levels. BAZZI et al. (2013) proposed the following procedure for selecting variables as input data for the Fuzzy C-Means algorithm. 1) Variables with spatial dependence and no significance at $95 \%$ significance are eliminated. 2) From variables with spatial dependence, those with no correlation with soybean yield are removed. 3) The descending order is calculated considering the degree of correlation with yield. 4) The redundant variables are eliminated (those that correlate with each other), giving preference to those variables with lower correlation with yield.

In this work, the redundant variables were not discarded, but different combinations of the variables were built, and each combination was defined as a MZ design. The combinations were constructed to assess whether redundant variables can harm the MZ delineation process.

According to the sample data for the selected variables, values were predicted for nonsampled regions in the studied field by the inverse of square distance. The data for the selected variables were normalized (Equation 2, MIELKE \& BERRY, 2007) to ensure that no variable had greater weight in the process of dividing the field into MZs.

$$
\mathrm{P}_{\mathrm{n}}=\frac{\mathrm{P}_{\mathrm{i}}-\text { Median }}{\text { Amplitude }}
$$

where,

$P_{i}$ is the pixel to be normalized and $P_{n}$ is the normalized pixel.

For each design, the field was divided into MZs according to an unsupervised classification fuzzy C-means algorithm (CANNON et al., 1986) using the software FuzMe (MINASNY \& MCBRATNEY, 2002). The software parameters included a minimum of two and a maximum of five MZ classes, Euclidean distances, a fuzzy exponent of 1.30, a maximum number of 300 interactions, and stopping criterion or error $\varepsilon=0.0001$. The Euclidean distance was adopted because the data were already normalized. The others constants were used as suggested.

The yields of the MZ designs were evaluated to determine the best way to divide the field. The following rating methods were used:

1) Variance Reduction: (PING; DOBERMANN, 2003; XIANG et al., 2007), (Equation 3) for yield was carried out, with expectations that the sum of the variances of the data of the $\mathrm{MZs}$ is lower than the total variance. 


$$
V R=1-\frac{\sum_{i=1}^{c}\left(W_{i} * V_{\mathrm{ZM}}\right)}{V_{\text {Field }}} * 100
$$

where,

$c$ is the number of management zones;

$W_{i}$ is the proportion of area each management zone;

$V_{Z M_{i}}$ is the variance of data each management zone, and

$V_{\text {Field }}$ is the sample variance of data to field.

2) Analysis of variance: used to verify that there are significant mean differences in yield among MZ classes in each proposed design (XIANG et al., 2007; MOLIN \& CASTRO, 2008; XIN-ZHONG et al., 2009). The HSD (Honest Significant Difference) Tukey test was applied at the 5\% level of significance. In each internal MZ class, the yield was considered an independent variable and normally distributed.

3) Cluster validation indices: FPI (Fuzziness Performance Index) and MPE (Modified Partition Entropy) indices were used (McBRATNEY \& MOORE, 1985, Equations 4 and 5) and were provided by FuzME software to assess whether the MZs with greater degrees of separation and organization among classes also corresponded to those with better RE indices. These indices have been applied in studies related to PA (MOLIN \& CASTRO, 2008; FU et al., 2010; GUASTAFERRO et al., 2010; ARNO et al., 2011). The cluster class (MZ) with the greatest differentiation was the one in which these two indices reached approximately the minimum in each design.

$$
\begin{aligned}
& \mathrm{FPI}=1-\frac{\mathrm{c}}{(\mathrm{c}-1)}\left[1-\frac{1}{n} \sum_{\mathrm{j}=1}^{\mathrm{n}} \sum_{\mathrm{i}=1}^{\mathrm{c}}\left(\mu_{\mathrm{ij}}\right)^{2}\right] \\
& \mathrm{MPE}=-\frac{1}{\mathrm{n}} \sum_{\mathrm{j}=1}^{\mathrm{n}} \sum_{\mathrm{i}=1}^{\mathrm{c}} \mu_{\mathrm{ij}} \log \left(\mu_{\mathrm{ij}}\right)
\end{aligned}
$$

where,

$c$ is the number of clusters;

$n$ is the number of observations, and

$\mu_{i j}$ is element $i j$ of fuzzy matrix $U$.

4) The Kappa index has been used to measure the accuracy of thematic classifications (BAZZI et al., 2008; BASTIANI et al., 2012; DALPOSSO et al., 2012) and is recommended as an appropriate measure of accuracy for all elements from the error matrix. It was used to evaluate the spatial agreement among maps of more efficient MZs (Equation 6).

$$
\mathrm{K}=\frac{\mathrm{n} \sum_{\mathrm{i}=1}^{\mathrm{r}} \mathrm{x}_{\mathrm{ii}}-\sum_{\mathrm{i}=1}^{\mathrm{r}}\left(\mathrm{x}_{\mathrm{i}+} \mathrm{x}_{+\mathrm{i}}\right)}{\mathrm{n}^{2}-\sum_{\mathrm{i}-1}^{\mathrm{r}}\left(\mathrm{x}_{\mathrm{i}+} \mathrm{x}_{+\mathrm{i}}\right)}
$$


where,

$K$ is the Kappa agreement index;

$n$ is the number of observations (sample points);

$r$ is the number of classes in the error matrix;

$x_{i i}$ is the number of combinations of row $i$ and column $i$;

$x_{i+}$ is the total observations of row $i ; x_{+i}$ is the total observations of column $i$.

The classification degree for Kappa index was defined according to LANDIS \& $\mathrm{KOCH}$ (1977) as follows: very strong, values between 0.81 to 1.00 ; strong, values from 0.61 to 0.80 ; moderate, values between 0.41 to 0.60 ; weak, values between 0.21 to 0.40 ; and no agreement, values between 0.00 and 0.20 .

\section{RESULTS AND DISCUSSION}

The contents of $\mathrm{C}, \mathrm{pH}$, clay content and altitude (Table 1) were highly homogeneous (PIMENTEL GOMES \& GARCIA, 2002), whereas soybean yield and the content attributes of Fe, $\mathrm{Mn}, \mathrm{Ca}$, silt, and soil resistance to penetration into layers at depths of $0-0.20 \mathrm{~m}$ (SRP_0_20) and 0.10 - $0.20 \mathrm{~m}$ (SRP_10_20) exhibited average homogeneity. The sample data for $\mathrm{Mg}$ content exhibited low homogeneity. Finally, $\mathrm{Cu}, \mathrm{Zn}, \mathrm{P}, \mathrm{Al}, \mathrm{K}$, sand and soil resistance to penetration in the 0 - $0.10 \mathrm{~m}$ layer (SRP_0_10) exhibited heterogeneity.

The soil texture (Table 1) was at least $60 \%$ clay, indicating a loamy soil. The field also exhibited significant compaction in the $0.10-0.20 \mathrm{~m}$ layer and greater resistance to penetration, as indicated by an average value of $1.94 \mathrm{MPa}$ and a maximum value of $2.40 \mathrm{MPa}$. The lowest soil compaction in the field was $0.31 \mathrm{MPa}$ in the layer from 0 to $0.10 \mathrm{~m}$.

TABLE 1. Descriptive statistics of the data.

\begin{tabular}{|c|c|c|c|c|c|c|c|c|}
\hline Attributes & $\mathrm{N}$ & Minimum & Mean & Median & Maximum & Standard deviation & $\mathrm{CV}(\%)$ & Normal* \\
\hline Yield $\left(\mathrm{t} \mathrm{ha}^{-1}\right)$ & 130 & 2.09 & 3.29 & 3.29 & 4.64 & 0.52 & $16(\mathrm{~m})$ & $\overline{\text { Yes }}$ \\
\hline $\mathrm{Cu}$ content $\left(\mathrm{mg} \mathrm{dm} \mathrm{dm}^{-3}\right)$ & 55 & 1.00 & 2.24 & 2.11 & 4.21 & 0.93 & 41 (vh) & Yes \\
\hline $\mathrm{Zn}$ content $\left(\mathrm{mg} \mathrm{dm}^{-3}\right)$ & 55 & 1.00 & 1.61 & 1.32 & 4.04 & 0.79 & 49 (vh) & No \\
\hline $\mathrm{Fe}$ content $\left(\mathrm{mg} \mathrm{dm}^{-3}\right)$ & 55 & 14.00 & 18.40 & 18.00 & 30.00 & 2.85 & $16(\mathrm{~m})$ & Yes \\
\hline Mn content $\left(\mathrm{mg} \mathrm{dm}^{-3}\right)$ & 55 & 37.00 & 49.65 & 49.00 & 68.00 & 6.69 & $13(\mathrm{~m})$ & Yes \\
\hline $\mathrm{P}$ content $\left(\mathrm{mg} \mathrm{dm}^{-3}\right)$ & 55 & 6.40 & 15.12 & 13.80 & 39.60 & 7.05 & 47 (vh) & No \\
\hline $\mathrm{C}$ content $\left(\mathrm{g} \mathrm{dm}^{-3}\right)$ & 55 & 28.05 & 33.08 & 33.12 & 37.79 & 2.39 & 7 (l) & Yes \\
\hline $\mathrm{pH}$ & 55 & 4.50 & 5.24 & 5.20 & 6.00 & 0.35 & 7 (1) & Yes \\
\hline $\mathrm{Ca}$ content $\left(\mathrm{cmolc} \mathrm{dm}^{-3}\right)$ & 55 & 3.79 & 6.74 & 6.75 & 9.90 & 1.34 & $20(\mathrm{~m})$ & Yes \\
\hline Mg content $\left(\right.$ cmolc $\left.\mathrm{dm}^{-3}\right)$ & 55 & 1.44 & 2.22 & 2.12 & 3.82 & 0.54 & $24(\mathrm{~h})$ & Yes \\
\hline Al content $\left(\mathrm{cmolc} \mathrm{dm}^{-3}\right)$ & 55 & 0.00 & 0.04 & 0.00 & 0.61 & 0.11 & 260 (vh) & Yes \\
\hline $\mathrm{K}$ content $\left(\mathrm{cmolc} \mathrm{dm}^{-3}\right)$ & 55 & 0.09 & 0.28 & 0.28 & 0.60 & 0.11 & 38 (vh) & Yes \\
\hline SRP_0_10 (MPa) & 55 & 0.31 & 0.62 & 0.63 & 1.09 & 0.20 & 31 (vh) & Yes \\
\hline SRP_0_20 (MPa) & 55 & 0.89 & 1.28 & 1.29 & 1.65 & 0.18 & $14(\mathrm{~m})$ & Yes \\
\hline SRP_10_20(MPa) & 55 & 1.43 & 1.94 & 1.96 & 2.40 & 0.20 & $11(\mathrm{~m})$ & Yes \\
\hline Altitude (m) & 55 & 701.0 & 706.3 & 702.0 & 712.0 & 3.33 & $0.5(1)$ & Yes \\
\hline Clay content (\%) & 45 & 60.00 & 70.00 & 72.00 & 79.00 & 5.00 & 7 (1) & No \\
\hline Sand content (\%) & 45 & 6.00 & 10.00 & 9.00 & 19.00 & 4.00 & 39 (vh) & No \\
\hline Silt content $(\%)$ & 45 & 15.00 & 20.00 & 19.00 & 25.00 & 2.00 & $11(\mathrm{~m})$ & Yes \\
\hline
\end{tabular}

$\mathrm{N}$ - Number of sampling units; *: Not Normal at 5\% significance; coefficient of variation (CV): low (l), medium (m), high (h), very high (vh); SRP_0_10: soil resistance to penetration at a depth of $0-0.10 \mathrm{~m}$; SRP_0_20: soil resistance to penetration in the layer at a depth of $0-0.20 \mathrm{~m}$; SRP_10_20: soil resistance to penetration in the $0.10-0.20 \mathrm{~m}$ layer. 
Most of the studied variables exhibited a normal distribution at 5\% significance, including yield, $\mathrm{Cu}, \mathrm{Fe}, \mathrm{Mn}, \mathrm{C}, \mathrm{pH}, \mathrm{Ca}, \mathrm{Mg}, \mathrm{Al}, \mathrm{K}, \mathrm{SRP}$ 0_10, SRP_0_20, SRP_10_20, altitude and silt (Table 1). The exceptions were the contents of $\mathrm{Zn}, \mathrm{P}$, clay and sand. Previous studies have also observed non-normality for clay (CORÁ et al., 2014), silt (ZUCOLOTO et al., 2011), P and Zn (LEÃO et al., 2010). No transformation was necessary for the variables that were not normal because these variables were not correlated with yield.

The average yield obtained in the study area was $3.29 \mathrm{t} \mathrm{ha}^{-1}$. The yield map (Figure 2) was generated by ordinary kriging interpolation, based on the best semivariogram, obtained with the Gaussian model (nugget effect in 0215 and reach $397 \mathrm{~m}$ ).

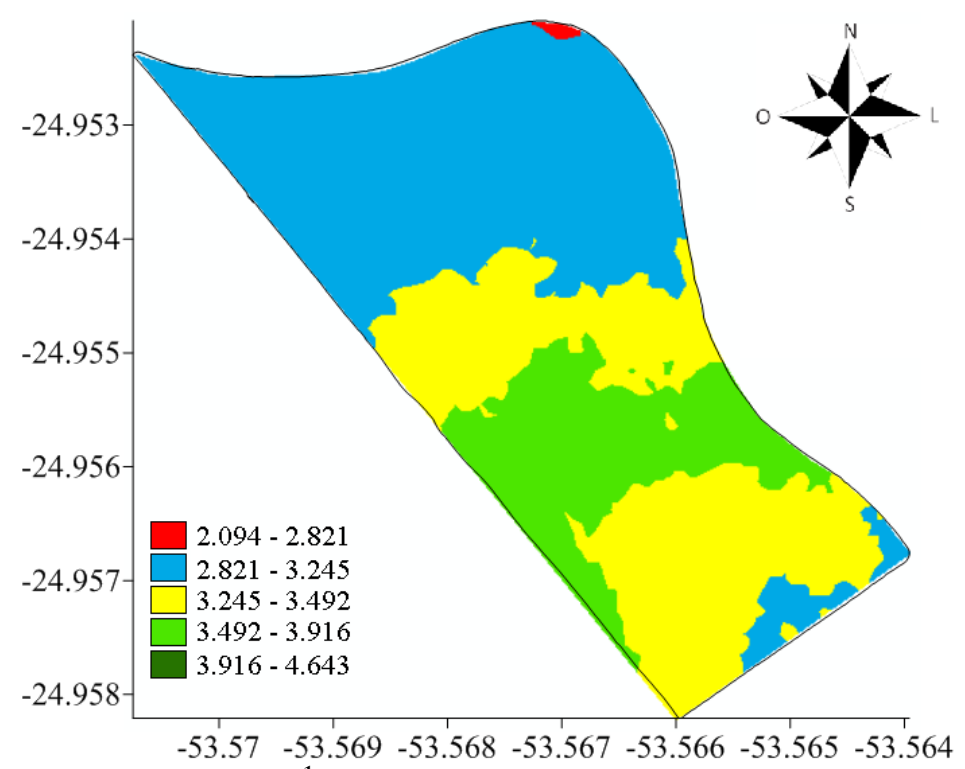

FIGURE 2. Soybean yield map $\left(\mathrm{t} \mathrm{ha}^{-1}\right)$ in a 19.6-ha commercial field, Municipality of Cascavel, Paraná, Brazil.

Based on the estimates of Moran's bivariate spatial autocorrelation statistic ( $I_{Y Z}$, Figures 3), variables such as $\mathrm{Cu}$, clay, silt and altitude have significant spatial autocorrelations (diagonal matrix) and significant spatial correlations with soybean yield. 


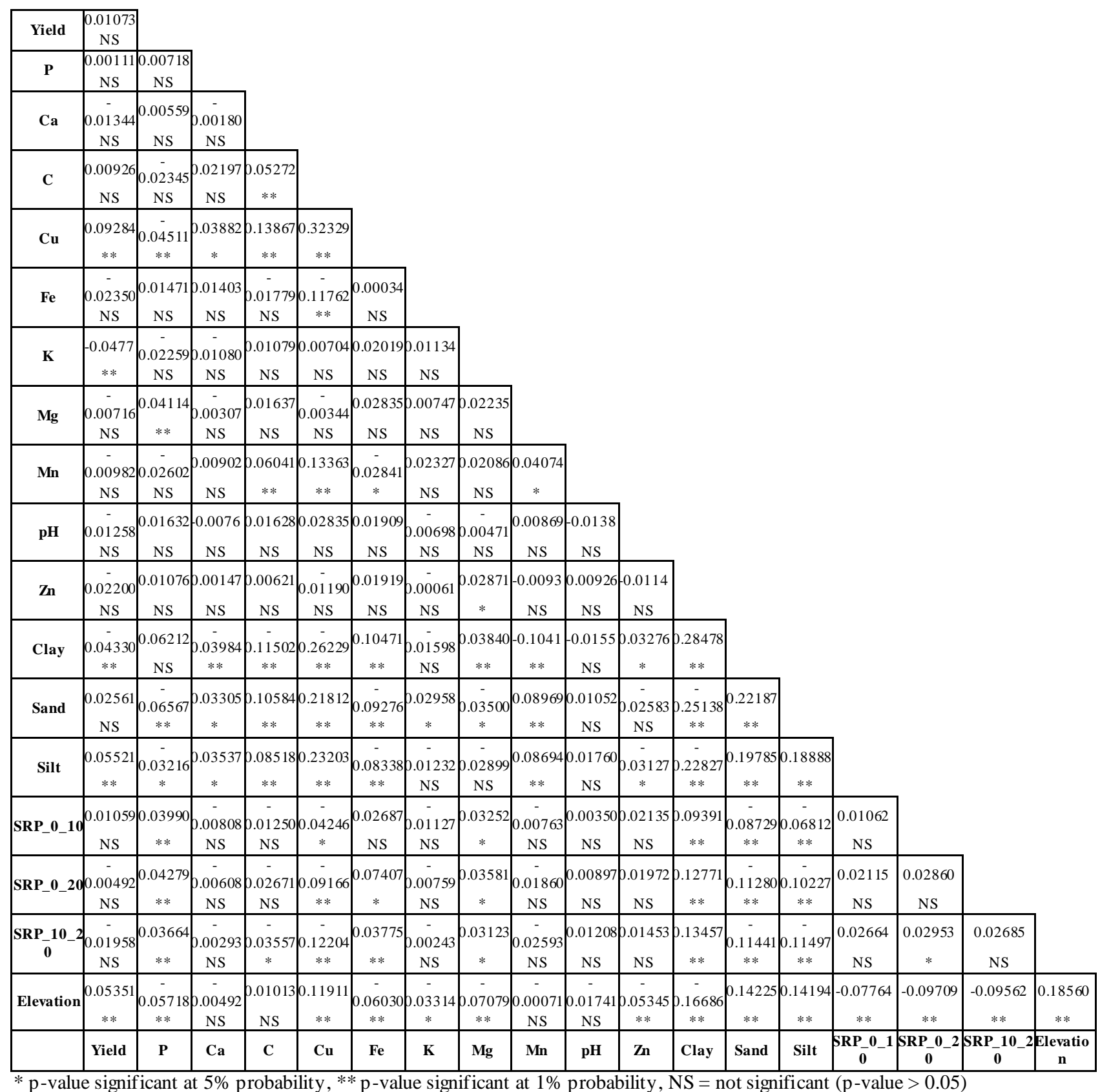

FIGURE 3. Bivariate spatial autocorrelation statistic of the analyzed chemical variables and yield in the studied field.

For a soil with the same characteristics as the soil studied here, BAZZI et al. (2013) also observed autocorrelation among these attributes $(\mathrm{Cu}$, clay and silt), but only clay and $\mathrm{Cu}$ were correlated spatially with soybean yield.

Based on the variables that exhibited both spatial autocorrelation spatial correlation with yield (copper, silt, altitude and clay, in order of decreasing importance), fifteen MZ designs (all possible combinations) were produced (Table 2). This table shows the calculated Moran's statistic. Because the values are not normalized, even small values of this statistic can be statistically significant (nonzero). The important outcome is whether the statistic is significant at 0.01 or 0.05 . 
TABLE 2. Combination of variables to generate management zones.

\begin{tabular}{ccc}
\hline Design & Acronym for design & Variables of design \\
\hline 1 & $01-\mathrm{CuSiAlCl}$ & Copper, Silt, Altitude and Clay \\
2 & $02-\mathrm{CuSiAl}$ & Copper, Silt and Altitude \\
3 & $03-\mathrm{CuSi}$ & Copper and Silt \\
4 & $04-\mathrm{Cu}$ & Copper \\
5 & $05-\mathrm{CuSiCl}$ & Copper, Silt and Clay \\
6 & $06-\mathrm{CuAlCl}$ & Copper, Altitude and Clay \\
7 & $07-\mathrm{SiAlCl}$ & Silt, Altitude and Clay \\
8 & $08-\mathrm{CuAl}$ & Copper and Altitude \\
9 & $09-\mathrm{CuCl}$ & Copper and Clay \\
10 & $10-\mathrm{SiAl}$ & Silt and Altitude \\
11 & $11-\mathrm{SiCl}$ & Silt and Clay \\
12 & $12-\mathrm{ClAl}$ & Clay and Altitude \\
13 & $13-\mathrm{Si}$ & Silt \\
14 & $14-\mathrm{Al}$ & Altitude \\
15 & $15-\mathrm{Cl}$ & Clay \\
\hline
\end{tabular}

Cu: copper; Si: silt; Al: altitude; Cl: clay.

The generated maps represent the division of the field in two, three, four and five classes (Figures 4-7) after the design of the division into MZs with FuzME. Thus, the maps present the MZs based on the previous interpolated variables, and thus no new interpolation was necessary to generate the maps. Good correlation can be seen between the yield map (Figure 2) and the MZs.

A. 01-CuSiAlCl

B. $02-\mathrm{CuSiAl}$

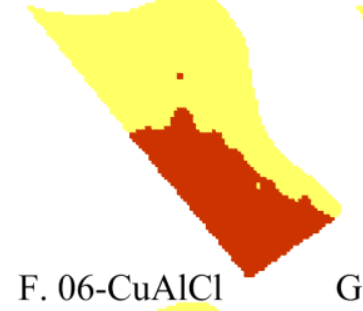

F. 06-CuAlCl

G. $07-\mathrm{SiAlCl}$
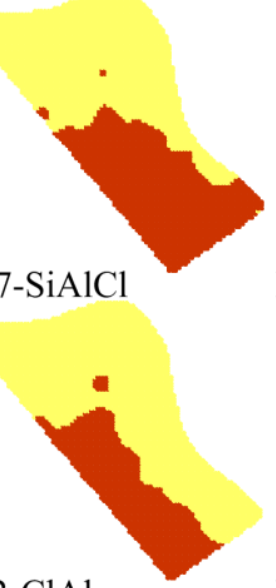

K. $11-\mathrm{SiCl}$

L. 12-ClAl
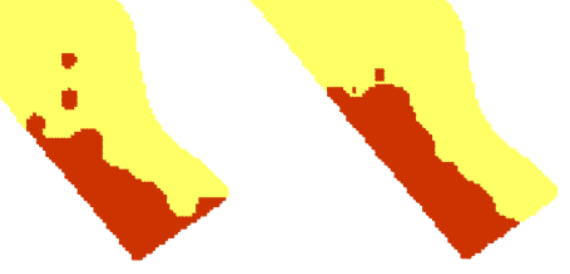

H. $08-\mathrm{CuAl}$

M. 13-Si

C. $03-\mathrm{CuSi}$

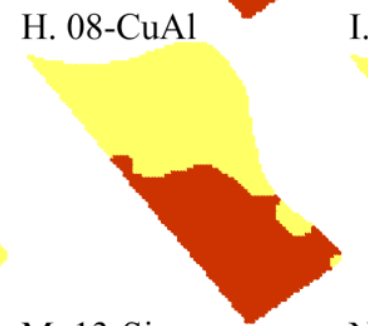

- 13 -Si

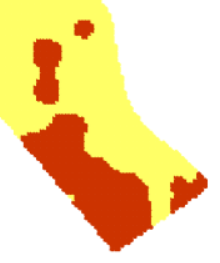

Class $1 \square$ Class 2
D. $04-\mathrm{Cu}$

N. $14-\mathrm{Al}$

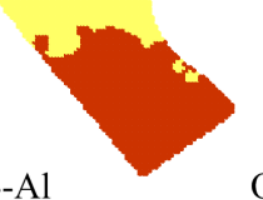

O. $15-\mathrm{Cl}$
E. $05-\mathrm{CuSiCl}$

J. 10-SiAl

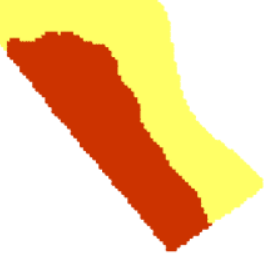

\section{党}
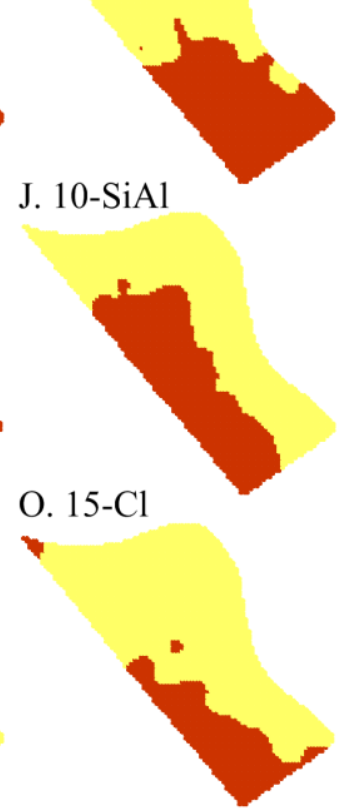

FIGURE 4. Designs of MZs divided into two classes. 


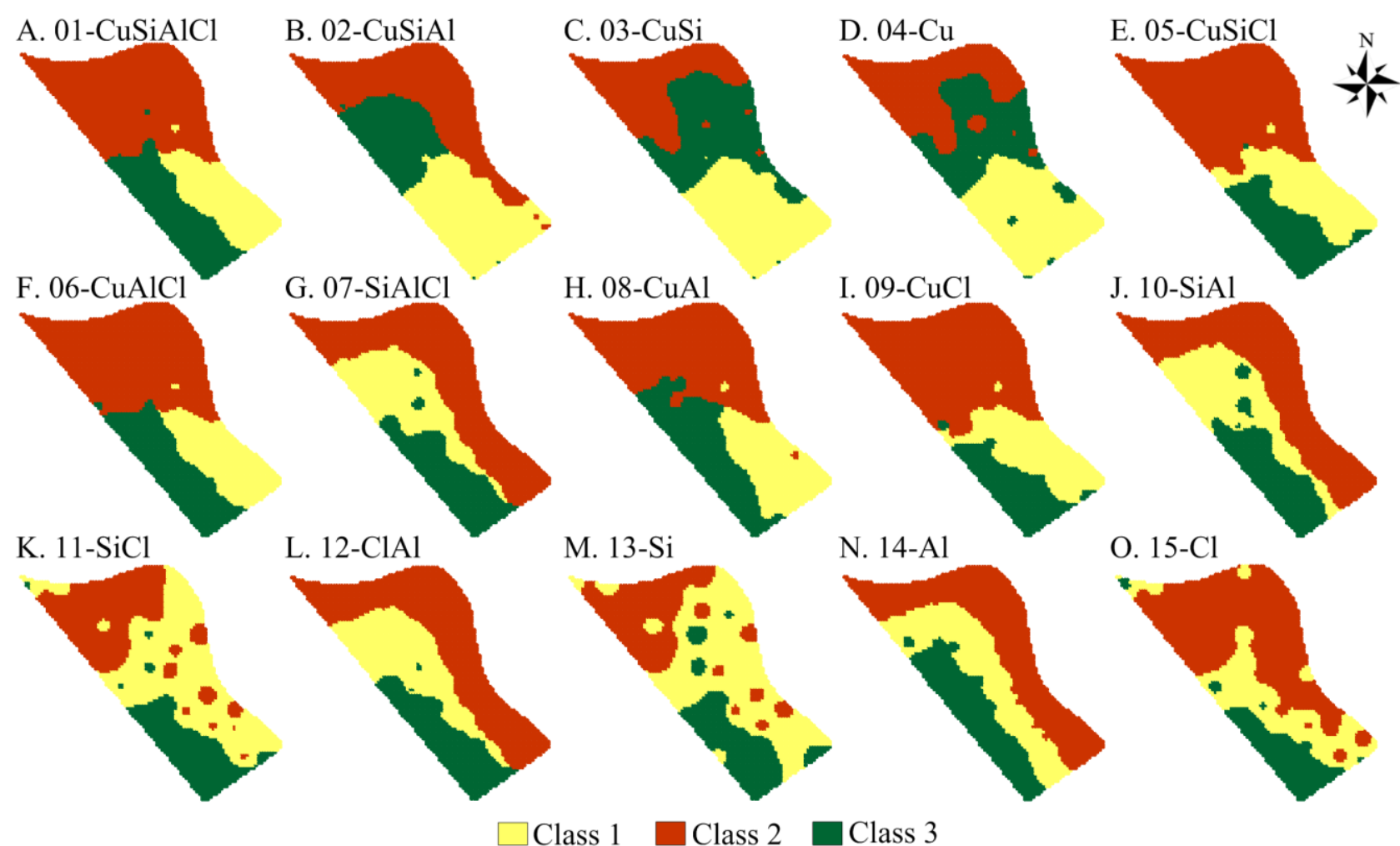

FIGURE 5. Designs of MZs divided into three classes.

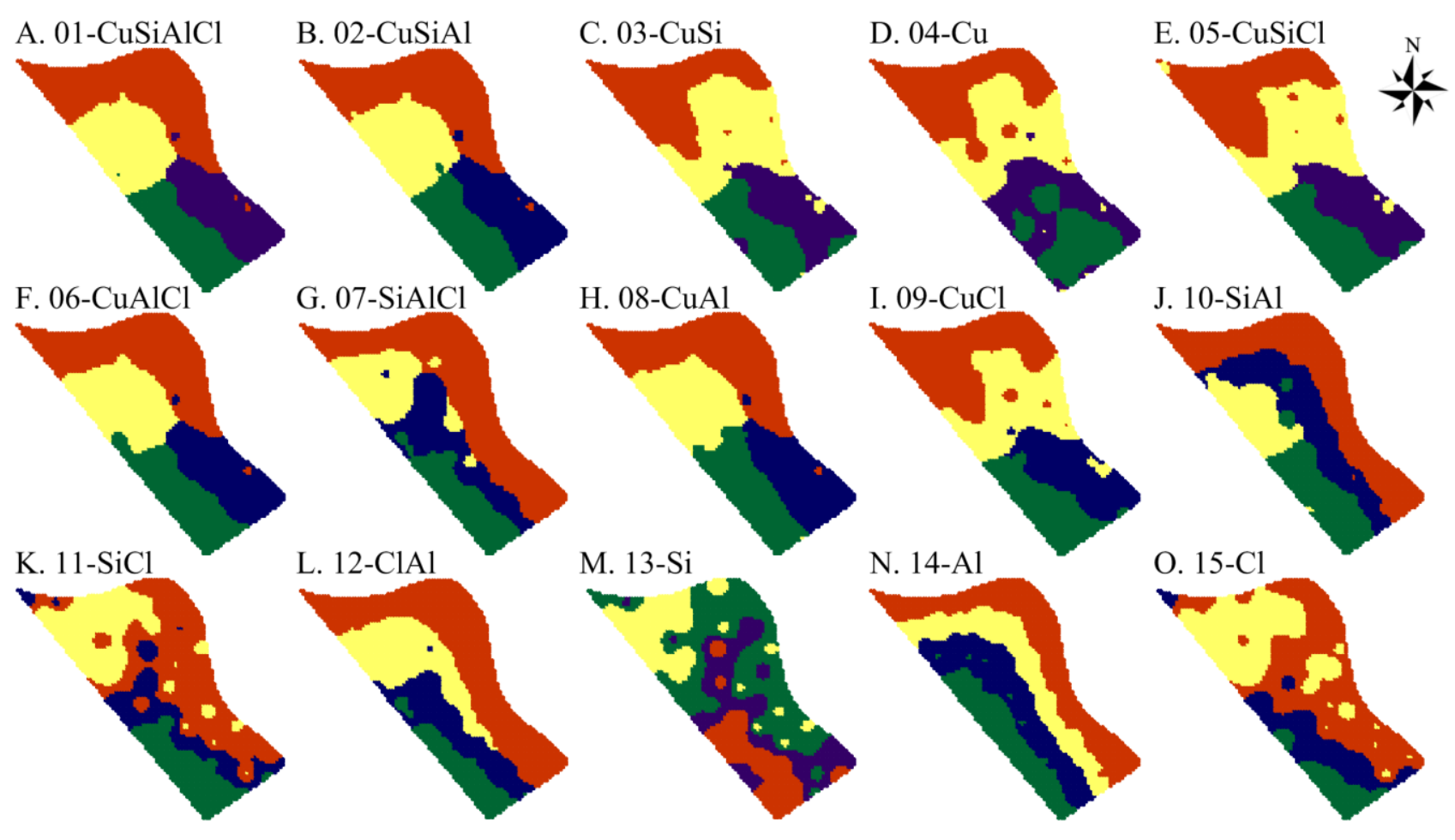

$\square$ Class $1 \square$ Class $2 \square$ Class $3 \square$ Class 4

FIGURE 6. Designs of MZs divided into four classes. 


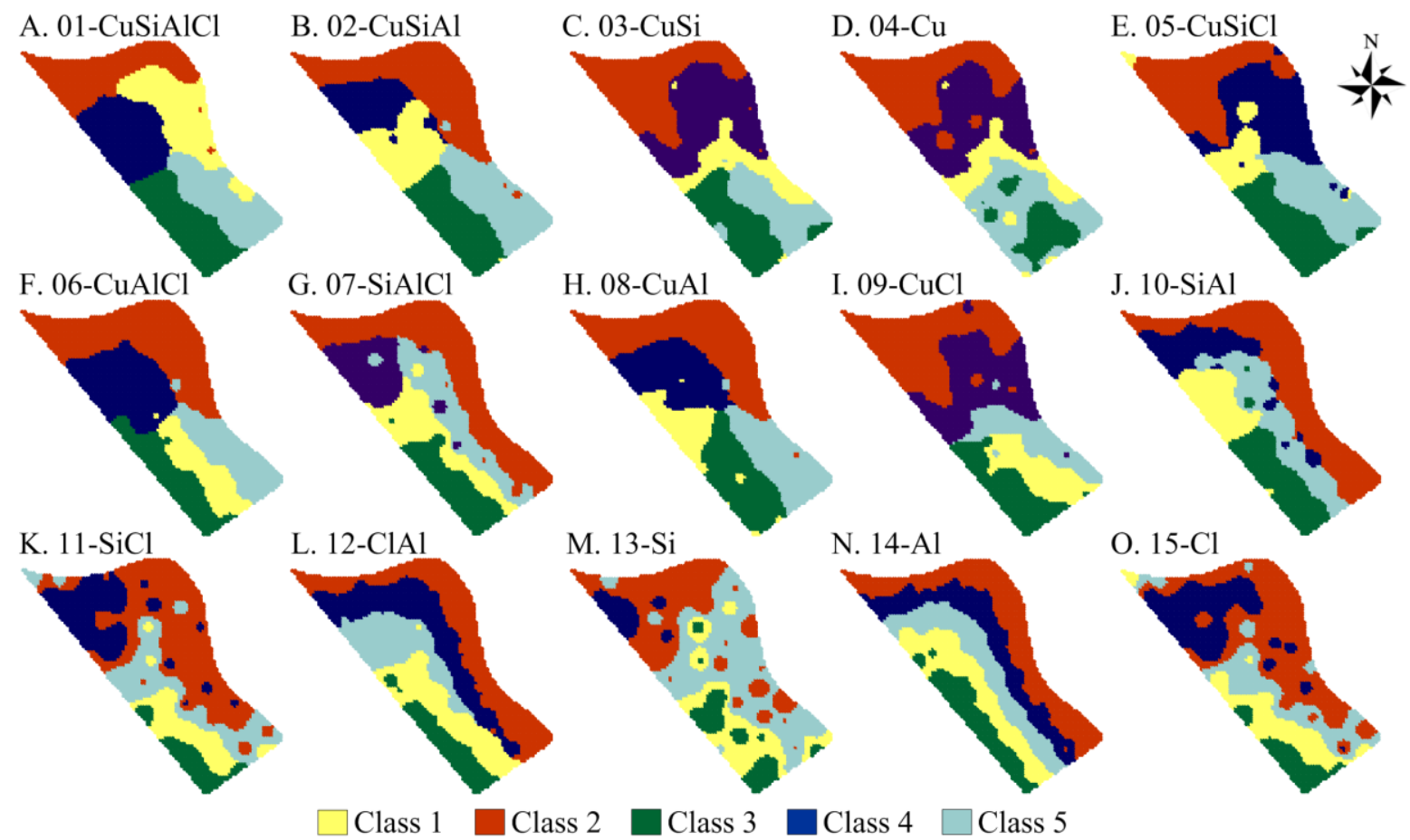

FIGURE 7. Designs of MZs divided into five classes.

Each MZ class (Figures 4-7) represents a group of data based on the variables used in each design. Because the studied variables exhibited a significant spatial correlation with soybean yield, the formed sub-regions (classes) tend to represent different potentials of soybean yield within the total field. The use of different combinations of the selected variables to generate MZs influences how the field is divided.

The soybean yield data were analyzed using Tukey's test to confirm that the MZs classes had different production potentials. The MZs were divided into two classes with significantly different averages for some designs (Table 3). The MZs that belonged to different classes were 01-CuSiAlCl, 02-CuSiAl, 03-CuSi, 04-Cu, 05-CuSiCl, 06-CuAlCl, 07-SiAlCl, 08-CuAl, 09-CuCl and 12-ClAl. ARNO et al. (2011) also determined by ANOVA that differences in yield were evident only when the field was subdivided into two MZs.

TABLE 3. Soybean yield averages in the MZ classes and comparison using Tukey's test at the 5\% level of significance.

\begin{tabular}{|c|c|c|c|c|c|c|c|c|c|c|c|c|c|c|c|}
\hline Division & D01 & D02 & D03 & D04 & D05 & D06 & D07 & D08 & D09 & D10 & D11 & D12 & D13 & D14 & D15 \\
\hline \multirow{2}{*}{2 classes } & $3.18 \mathrm{a}$ & $3.14 \mathrm{a}$ & $3.15 \mathrm{a}$ & $3.14 \mathrm{a}$ & $3.17 \mathrm{a}$ & $3.16 \mathrm{a}$ & $3.21 \mathrm{a}$ & $3.14 \mathrm{a}$ & $3.15 \mathrm{a}$ & $3.22 \mathrm{a}$ & $3.25 \mathrm{a}$ & $3.21 \mathrm{a}$ & $3.26 \mathrm{a}$ & $3.21 \mathrm{a}$ & 3.25 \\
\hline & $3.44 \mathrm{~b}$ & $3.45 \mathrm{~b}$ & $3.45 \mathrm{~b}$ & $3.46 \mathrm{~b}$ & $3.45 \mathrm{~b}$ & $3.46 \mathrm{~b}$ & $3.45 \mathrm{~b}$ & $3.45 \mathrm{~b}$ & $3.45 \mathrm{~b}$ & $3.39 \mathrm{a}$ & $3.37 \mathrm{a}$ & $3.43 \mathrm{~b}$ & $3.35 \mathrm{a}$ & $3.38 \mathrm{a}$ & .0 \\
\hline \multirow{3}{*}{3 classes } & $3.10 \mathrm{a}$ & $3.10 \mathrm{a}$ & $3.03 \mathrm{a}$ & $3.04 \mathrm{a}$ & $3.12 \mathrm{a}$ & $3.10 \mathrm{a}$ & $3.19 \mathrm{a}$ & $3.10 \mathrm{a}$ & $3.13 \mathrm{a}$ & $3.19 \mathrm{a}$ & $3.12 \mathrm{a}$ & $3.20 \mathrm{a}$ & $3.18 \mathrm{a}$ & $3.18 \mathrm{a}$ & 3.15 \\
\hline & $3.45 \mathrm{~b}$ & $3 a b$ & $3.34 \mathrm{~b}$ & $34 \mathrm{~b}$ & $3.41 \mathrm{~b}$ & $3.39 \mathrm{~b}$ & $3.30 \mathrm{a}$ & $4 \mathrm{ab}$ & $3.42 \mathrm{~b}$ & $3.26 \mathrm{ab}$ & $3.34 \mathrm{ab}$ & $3.28 \mathrm{a}$ & $3.31 \mathrm{a}$ & $3.28 \mathrm{ab}$ & 3.45 \\
\hline & $3.46 \mathrm{~b}$ & $46 \mathrm{~b}$ & $3.45 \mathrm{~b}$ & $3.45 \mathrm{~b}$ & $3.52 \mathrm{~b}$ & $3.51 \mathrm{~b}$ & $3.45 \mathrm{a}$ & $3.50 \mathrm{~b}$ & $3.49 \mathrm{~b}$ & $3.51 \mathrm{~b}$ & $3.42 \mathrm{~b}$ & $3.46 \mathrm{a}$ & $3.35 \mathrm{a}$ & $3.48 \mathrm{~b}$ & 3.47 \\
\hline \multirow{4}{*}{4 classes } & $3.06 \mathrm{a}$ & $3.07 \mathrm{a}$ & $3.04 \mathrm{a}$ & $3.04 \mathrm{a}$ & $3.03 \mathrm{a}$ & $3.07 \mathrm{a}$ & $3.20 \mathrm{a}$ & $3.07 \mathrm{a}$ & $3.01 \mathrm{a}$ & $3.12 \mathrm{a}$ & $3.09 \mathrm{a}$ & $3.20 \mathrm{a}$ & $3.17 \mathrm{a}$ & $3.14 \mathrm{a}$ & 3.09 \\
\hline & $3.34 \mathrm{ab}$ & $3.29 \mathrm{ab}$ & $3.29 \mathrm{ab}$ & $3.26 \mathrm{a}$ & $3.30 \mathrm{ab}$ & $3.31 \mathrm{ab}$ & $3.21 \mathrm{a}$ & $3.28 \mathrm{ab}$ & $3.36 \mathrm{~b}$ & $3.27 \mathrm{ab}$ & $3.17 \mathrm{ab}$ & $3.25 \mathrm{a}$ & $3.29 \mathrm{a}$ & $3.27 \mathrm{a}$ & 3.23 \\
\hline & $3.39 \mathrm{~b}$ & $3.42 \mathrm{~b}$ & $3.35 \mathrm{ab}$ & $3.33 \mathrm{ab}$ & $3.41 \mathrm{~b}$ & $3.35 \mathrm{ab}$ & $3.30 \mathrm{a}$ & $3.36 \mathrm{ab}$ & $3.43 \mathrm{~b}$ & $3.37 \mathrm{ab}$ & $3.33 \mathrm{ab}$ & $3.39 \mathrm{a}$ & $3.33 \mathrm{a}$ & $3.34 \mathrm{c}$ & 39 \\
\hline & $3.48 \mathrm{~b}$ & $3.48 \mathrm{~b}$ & $3.55 \mathrm{~b}$ & $3.58 \mathrm{~b}$ & $3.49 \mathrm{~b}$ & $3.51 \mathrm{~b}$ & $3.52 \mathrm{a}$ & $3.52 \mathrm{~b}$ & $3.46 \mathrm{~b}$ & $3.50 \mathrm{~b}$ & $3.50 \mathrm{~b}$ & $3.51 \mathrm{a}$ & $3.37 \mathrm{a}$ & $3.47 \mathrm{a}$ & 3.53 \\
\hline \multirow{5}{*}{5 classes } & $3.00 \mathrm{a}$ & $3.09 \mathrm{a}$ & $3.01 \mathrm{a}$ & $3.05 \mathrm{a}$ & $3.02 \mathrm{a}$ & $3.04 \mathrm{a}$ & $3.14 \mathrm{a}$ & $3.07 \mathrm{a}$ & $3.02 \mathrm{a}$ & $3.17 \mathrm{a}$ & $3.07 \mathrm{a}$ & $3.14 \mathrm{a}$ & $2.92 \mathrm{a}$ & $3.15 \mathrm{a}$ & 3.08 \\
\hline & $3.19 \mathrm{ab}$ & $3.16 \mathrm{a}$ & $3.23 \mathrm{ab}$ & $3.21 \mathrm{ab}$ & $3.24 \mathrm{ab}$ & $3.28 \mathrm{ab}$ & $3.19 \mathrm{a}$ & $3.27 \mathrm{a}$ & $3.26 \mathrm{ab}$ & $3.18 \mathrm{a}$ & $3.23 \mathrm{ab}$ & $3.22 \mathrm{a}$ & $3.20 \mathrm{ab}$ & $3.21 \mathrm{a}$ & 3.18 \\
\hline & $3.35 \mathrm{ab}$ & $3.40 \mathrm{a}$ & $39 \mathrm{ab}$ & $3.22 \mathrm{ab}$ & $3.30 \mathrm{ab}$ & 3.3 & a & $3.41 \mathrm{a}$ & $3.27 \mathrm{ab}$ & $3.31 \mathrm{a}$ & $3.27 \mathrm{ab}$ & $3.27 \mathrm{a}$ & $3.27 \mathrm{ab}$ & $3.30 \mathrm{a}$ & 3.25 \\
\hline & $3.43 \mathrm{~b}$ & $3.42 \mathrm{a}$ & $3.48 \mathrm{~b}$ & $3.50 \mathrm{~b}$ & $3.41 \mathrm{ab}$ & $3.45 \mathrm{~b}$ & $3.40 \mathrm{a}$ & $3.41 \mathrm{a}$ & $3.52 \mathrm{~b}$ & $3.32 \mathrm{a}$ & $3.33 \mathrm{ab}$ & $3.39 \mathrm{a}$ & $3.38 \mathrm{ab}$ & $3.39 \mathrm{a}$ & 3.53 \\
\hline & $3.48 \mathrm{~b}$ & $3.44 \mathrm{a}$ & $3.48 \mathrm{~b}$ & $3.52 \mathrm{~b}$ & $3.49 \mathrm{~b}$ & $3.55 \mathrm{~b}$ & $51 \mathrm{a}$ & $3.44 \mathrm{a}$ & $3.56 \mathrm{~b}$ & $3.52 \mathrm{a}$ & $3.58 \mathrm{~b}$ & $3.53 \mathrm{a}$ & $3.42 \mathrm{~b}$ & $3.50 \mathrm{a}$ & 3.55 \\
\hline
\end{tabular}

The designs refer to Table 2. D01: 01-CuSiAlCl; D02: 02-CuSiAl; D03: 03-CuSi; D04: 04-Cu; D05: 05-CuSiCl; D06: 06-CuAlCl; D07: 07-SiAlCl; D08: 08-CuAl; D09: 09-CuCl; D10: 10-SiAl; D11: 11-SiCl; D12: 12-ClAl; D13: 13-Si; D14: 14-Al; D15: 15-Cl.

As shown in Figure 8, none of the MZs exhibited RE values less than one. The following MZs had relative efficiencies of 1: 11-SiCl, which contains two classes; 13-Si, which contains 2, 3 and 4 classes; and 15-Cl, which contains two classes. Thus, these forms of division into MZs will 
not reduce the variance of the yield, in agreement with Tukey's test (Table 3), which revealed no significant differences among the yields. The other MZs with RE > 1 exhibited a variance reduction, suggesting that the se divisions can be used as a source of recommendation and analysis.

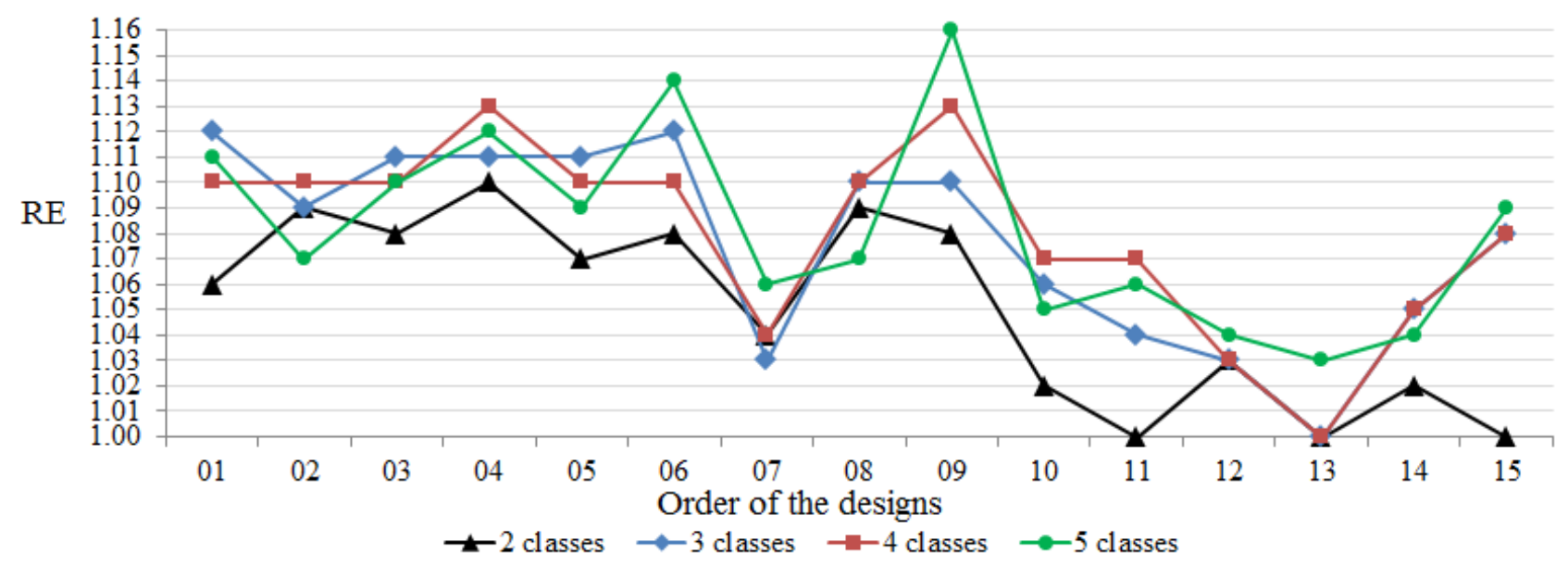

FIGURE 8. Performance of divisions in the management zone according to Relative Efficiency (RE). The order of the designs is 01-CuSiAlCl; 02-CuSiAl; 03-CuSi; 04-Cu; 05CuSiCl; 06-CuAlCl; 07-SiAlCl; 08-CuAl; 09-CuCl; 10-SiAl; 11-SiCl; 12-ClAl; 13-Si; 14-Al; and 15-Cl.

The division of the 09- $\mathrm{CuCl} \mathrm{MZs} \mathrm{(Figure} \mathrm{9)} \mathrm{into} 5$ classes resulted in the highest RE (1.16) among all the MZs. For division into four $\mathrm{MZs}, 04-\mathrm{Cu}$ and $09-\mathrm{CuCl}$ designs reduced the yield variance most effectively ( $\mathrm{RE}=1.13$ ). Combinations $01-\mathrm{CuSiAlCl}$ and $06-\mathrm{CuAlCl}$ exhibited higher $\mathrm{RE}$ (1.12) compared to the other divisions in three classes. By contrast, for divisions into two classes, the 04-Cu design had the highest RE (1.10). In general, the RE values were highest in divisions with higher numbers of classes, although for 3, 4 and 5 classes, not all means differed from each other within each design (Table 3).

According to the calculated values of FPI and MPE (Figure 9), the designs in which fewer variables were used exhibited better separation and organization of data among the MZ classes, as indicated by the low values for these indices. Thus, designs such as $04-\mathrm{Cu}, 13-\mathrm{Si}, 14-\mathrm{Al}$ and $15-\mathrm{Cl}$, in which only one variable was used to divide MZs, exhibited the lowest levels of FPI and MPE. However, only the 04- $\mathrm{Cu}$ design had a high $\mathrm{RE}$, whereas the 13-Si, 14-Al and 15-Cldesigns had, in general, the lowest RE values.

When the variable $\mathrm{Cu}$ was not included in the evaluation, the MZs were less effective (low RE, Figure 9) and did not all exhibit differences in means in each design (Tukey test), such as the following cases: 10-SiAl 11-SiCl, 12-ClAl, 13-Si, 14- $\mathrm{Al}$ and 15-Cl. An exception was the 07SiAlCldesign (Table 3). 

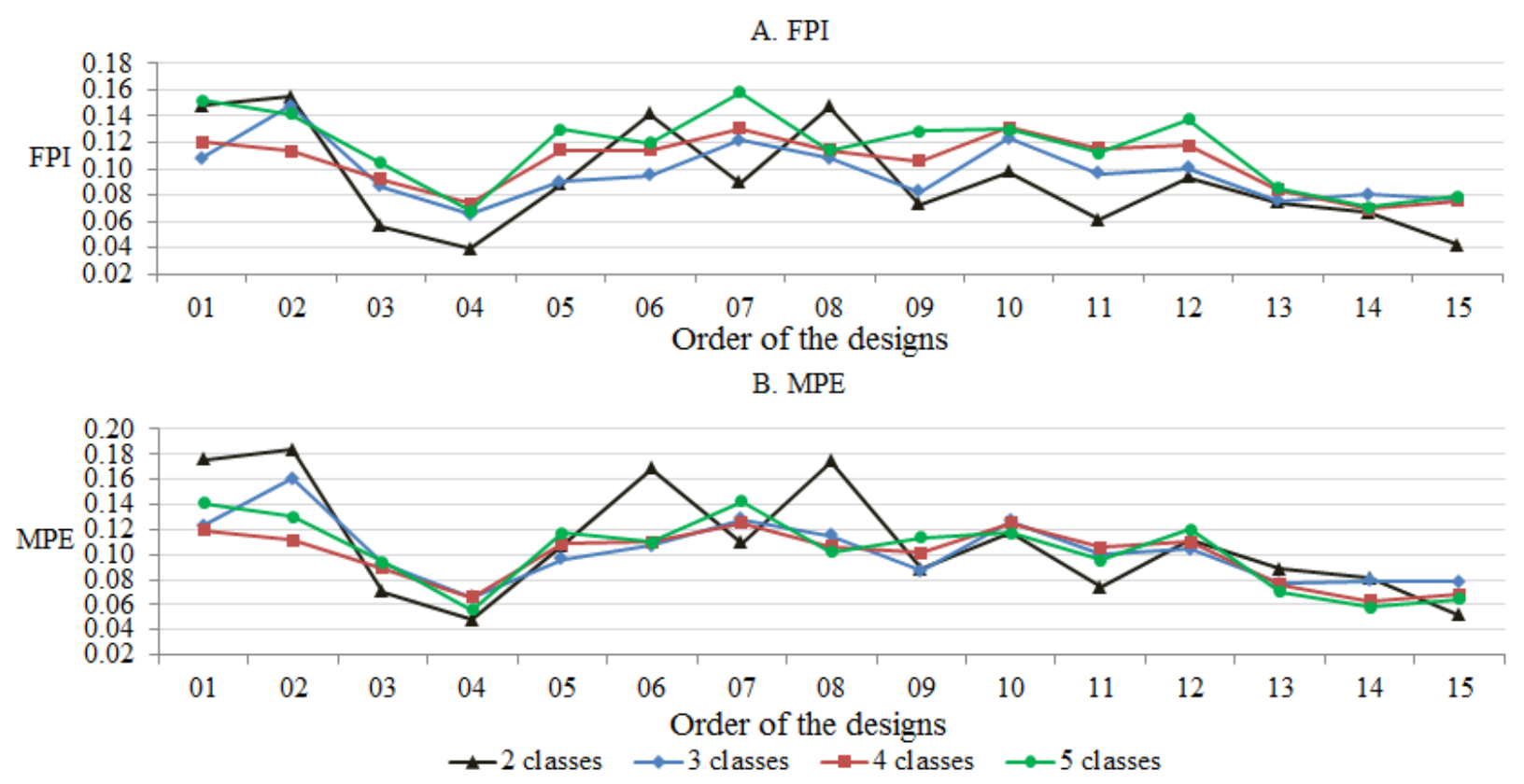

FIGURE 9. Performance of divisions in the management zone according to FPI (Fuzziness Performance Index) and MPE (Modified Partition Entropy). The order of the designs is 01-CuSiAlCl; 02-CuSiAl; 03-CuSi; 04-Cu; 05-CuSiCl; 06-CuAlCl; 07-SiAlCl; 08-CuAl; 09-CuCl; 10-SiAl; 11-SiCl; 12-ClAl; 13-Si; 14-Al; and 15-Cl.

Six designs of MZs were compared using the Kappa index (Table 4). These MZs used the variable $\mathrm{Cu}$ and in general had higher $\mathrm{RE}$ values in divisions of 2 to 5 classes (01-CuSiAlCl, 02$\mathrm{CuSiAl}, 03-\mathrm{CuSi}, 04-\mathrm{Cu}, 06-\mathrm{CuAlCl}$ and $09-\mathrm{CuCl}$ ). The objective was to evaluate the degree of visual agreement among the maps of 2, 3, 4 and 5 classes.

For the MZs that were divided into two classes, there was greater visual agreement among the compared maps. Eight comparisons were in very strong agreement, whereas seven comparisons yielded strong agreement. There were lower levels of agreement among the visual maps for MZs divided into 3, 4 and 5 classes. However, the difference was greatest for MZs divided into 5 classes; two comparisons exhibited strong agreement, seven moderate and six weak.

TABLE 4. Kappa index among maps divided into management zones with 2, 3, 4 and 5 classes for the experimental designs 01-CuSiAlCl, 02-CuSiAl, 03-CuSi, 04-Cu, 06-CuAlCl and 09- $\mathrm{CuCl}$.

\begin{tabular}{ccccc}
\hline Compared experimental designs & 2 classes & 3 classes & 4 classes & 5 classes \\
\hline 01-CuSiAlCl x 02-CuSiAl & $\underline{0.87(\mathrm{VS})}$ & $0.31(\mathrm{~W})$ & $\underline{0.96(\mathrm{VS})}$ & $0.59(\mathrm{MO})$ \\
01-CuSiAlCl x 03-CuSi & $0.72(\mathrm{~S})$ & $0.30(\mathrm{~W})$ & $0.61(\mathrm{~S})$ & $0.61(\mathrm{~S})$ \\
01-CuSiAlCl x 04-Cu & $0.69(\mathrm{~S})$ & $0.30(\mathrm{~W})$ & $0.42(\mathrm{MO})$ & $0.44(\mathrm{MO})$ \\
01-CuSiAlCl x 06-CuAlCl & $\underline{0.95(\mathrm{VS})}$ & $0.97(\mathrm{VS})$ & $\underline{0.95(\mathrm{VS})}$ & $0.35(\mathrm{~W})$ \\
01-CuSiAlCl x 09-CuCl & $\underline{0.76(\mathrm{~S})}$ & $\underline{0.85(\mathrm{VS})}$ & $0.64(\mathrm{~S})$ & $0.48(\mathrm{MO})$ \\
02-CuSiAl x 03-CuSi & $\underline{0.83(\mathrm{VS})}$ & $0.56(\mathrm{MO})$ & $0.60(\mathrm{MO})$ & $0.38(\mathrm{~W})$ \\
02-CuSiAl x 04-Cu & $\underline{0.80(\mathrm{~S})}$ & $0.56(\mathrm{MO})$ & $0.40(\mathrm{~W})$ & $0.25(\mathrm{~W})$ \\
02-CuSiAl x 06-CuAlCl & $\underline{0.89(\mathrm{VS})}$ & $0.31(\mathrm{~W})$ & $\underline{0.96(\mathrm{VS})}$ & $0.59(\mathrm{MO})$ \\
02-CuSiAl x 09-CuCl & $\underline{0.86(\mathrm{VS})}$ & $0.90(\mathrm{VS})$ & $0.61(\mathrm{~S})$ & $0.29(\mathrm{~W})$ \\
03-CuSi x 04-Cu & $\underline{0.74(\mathrm{~S})}$ & $0.29(\mathrm{~W})$ & $0.57(\mathrm{MO})$ & $0.71(\mathrm{~S})$ \\
03-CuSi x 06-CuAlCl & $\underline{0.96(\mathrm{VS})}$ & $0.33(\mathrm{~W})$ & $\underline{0.86(\mathrm{VS})}$ & $0.38(\mathrm{~W})$ \\
03-CuSi x 09-CuCl & $\underline{0.71(\mathrm{~S})}$ & $0.29(\mathrm{~W})$ & $0.38(\mathrm{~W})$ & $0.29(\mathrm{~W})$ \\
04-Cu x 06-CuAlCl & $\underline{0.93(\mathrm{VS})}$ & $0.34(\mathrm{~W})$ & $0.67(\mathrm{~S})$ & $0.48(\mathrm{MO})$ \\
04-Cu x 09-CuCl & $0.78(\mathrm{~S})$ & $\underline{0.83(\mathrm{VS})}$ & $0.60(\mathrm{MO})$ & $0.52(\mathrm{MO})$ \\
06-CuAlCl x 09-CuCl & & & &
\end{tabular}


The 04-Cu experimental design displayed good results for RE, FPI and MPE, very strong agreement with the 03-CuSi and 09-CuCl designs and strong agreement with the 01-CuSiAlCl, 02$\mathrm{CuSiAl}$ and 06-CuAlCl experimental designs for the division of MZs into 2 classes. For MZs divided into three classes, the $\mathrm{Cu}-04$ design exhibited very strong agreement with the 03-CuSi design. For MZs divided into 4 and 5 classes, the 04-Cu design exhibited strong agreement with the 03-CuSi design.

\section{CONCLUSIONS}

Some combinations of these variables that were cross-correlated produced better MZs. None of the variable combinations produced a statistically better performance than the MZ generated using only copper, i.e., the design with only no redundant variables. Thus, the other redundant variables can be discredited. The design with all variables did not provide a greater separation and organization of data among MZ classes.

\section{ACKNOWLEDGEMENTS}

The authors are grateful to the State University of Western Paraná (UNIOESTE), the Araucária Foundation (Fundação Araucária), the Coordination for the Improvement of Higher Education Personnel (CAPES), the National Council for Scientific and Technological Development (CNPq), and Technological Federal University of Paraná for support. The authors are also grateful to Agassiz Linhares Neto, the engineer who allowed use of the field where the data were collected.

\section{REFERENCES}

ARNO, J.; MARTINEZ-CASASNOVAS, J. A.; RIBES-DASI, M.; ROSSEL, J. R. Clustering of grape yield maps to delineate site-specific. Spanish Journal of Agricultural Research, Washington, v. 9, n. 3, p. 721-729, 2011.

BANSOD, B. S.; PANDEY, O. P. An application of PCA and fuzzy C-means to delineate management zones and variability analys is of soil. Eurasian Soil Science, Silver Spring, v. 46, n. 5, p. 556-564, 2013.

BASTIANI, F. de; URIBE-OPAZO, M. A.; DALPOSSO, G. H. Comparison of maps of spatial variability of soil resistance to penetration constructed with and without covariables using a spatial linear model. Engenharia Agrícola, Jaboticabal, v. 32, n. 2, p. 393-404, 2012.

BAZZI, C. L.; SOUSA, E. G.; URIBE-OPAZO, M. A.; NÓBREGA, L. H. P.; PINHEIRO R. Influência da distância entre passadas de colhedora equipada com monitor de colheita na precisão dos mapas de produtividade na cultura do milho. Engenharia Agrícola, Jaboticabal, v. 28, n. 2, p. 355-363, 2008.

BAZZI, C. L. ; SOUZA, E. G. ; Uribe-Opazo, M. A. ; Nóbrega, L. H. P. ; ROCHA, D. M. Management zones definition using soil chemical and physical attributes in a soybea $n$ area.

Engenharia Agrícola, Jaboticabal, v. 34, n.5, p. 952-964, 2013.

BEZDEK, C. J. Pattern recognition with fuzzy objective function algorithms. New York: Plenum Press, 1981. 256 p.

BONHAM C. D.; REICH R. M.; LEADER K. K. Spatial cross-correlation of Bouteloua gracilis with site factors. Grassland Science, Oxford, v. 41, n. 3, p. 196-201, 1995.

BURROUGH, P.A. Fuzzy mathematical methods for soil survey and land evaluation. Journal of Soil Science, Oxford, n.40, p.477-492, 1989.

CANNON, R. L.; DAVE, J. V.; BEZDEK, J. C. Efficient implementation of the Fuzzy C-means clustering algorithms. IEEE Transactions on Pattern Analysis and Machine Intelligence, New York, v.8, n.2, p.248-255, 1986. 
CORÁ, J. E.; ARAUJO, A. V.; PEREIRA, G. T.; BERALDO, J. M. G. Variabilidade espacial de atributos do solo para adoção do sistema de agricultura de precisão na cultura de cana-de-açúcar.

Revista Brasileira de Ciência do Solo, Viçosa, MG, v. 28, n. 6, p. 1013-1021, 2014.

DAVATGAR, N.; NEISHABOURI, M. R.; SEPASKHAH, A. R. Delineation of site specific nutrient management zones for a paddy cultivated area based on soil fertility using fuzzy clustering. Geoderma, Amsterdam, v. 173-174, n. 1, p. 111-118, 2012.

DALPOSSO, G. H.; URIBE-OPAZO, M. A.; MERCANTE, E.; JOHANN, J. A.; BORSSOI, J. A. Comparison measures of maps generated by geostatistical methods. Engenharia Agrícola, Jaboticabal, v. 32, n. 1, p. 174-183, 2012.

DOERGE, T. A. Site-specific manage ment guidelines. Norcross: Potash \& Phosphate Institute, 2000. $135 \mathrm{p}$.

FU, Q.; WANG, Z.; JIANG, Q. Delineating soil nutrient management zones based on fuzzy clustering optimized by PSO. Mathematical and Compute r Modelling, Oxford, v. 51, n. 11-12, p. 1299-1305, 2010.

GOOGLE EARTH. Versão 5.0. Software de imagens. 2009. Ano da imagem: 6 mar. 2010. Disponível em <http://earth.google.com>. Acesso em: 13 abr. 2011.

GUASTAFERRO, F.; CASTRIGNANO, A.; BENEDETTO, A. de; SOLLITTO, D.; TROCCOLI, A.; CAFARELLI, B. A comparison of different algorithms for the delineation of management zones. Precision Agriculture, Dordrecht, v. 11, n. 6, p. 600-620, 2010.

ILIADIS, L.S.; VANGELOUDH, M.; SPARTALIS,S. An inteligent system employing an enhanced fuzzy C-Means clustering model: Application in the case of forest fires. Computers and Eletronics in Agriculture, Netherlands, v.70, n.1, p.276-284, 2010.

JOHNSON, D.E. Applied multivariate methods for data analysis. Pacific Grove: Brooks/Cole Publ., 1998. 567 p.

KWEON, G. Delineation of site-specific productivity zones using soil properties and topographic attributes with a fuzzy logic system. Biosystems Engineering, London, v. 112, n. 4, p. 261-277, 2012.

LANDIS, J. R.; KOCH, G. G. The measurement of observer agreement for categorical data. Biometrics, Arlington, v. 33, n. 1, p. 159-174, mar. 1977.

LEÃO, M. G. A. de; MARQUES JÚNIOR, J.; SOUZA, Z. M. de; SIQUEIRA, D. S.; PEREIRA, G. O relevo na interpretação da variabilidade espacial dos teores de nutrientes em folha de citros.

Revista Brasileira de Engenharia Agrícola e Ambiental, Campina Grande, v. 14, n. 11, p. 11521159, 2010.

LI, Y.; SHI, Z.; WU, H.; LI, F.; LI, H. Definition of management zones for enhancing cultivated land conservation using combined spatial data. Environmental Management, New York, v. 52, p. 792-806, 2013.

MCBRATNEY, A. B.; MOORE, A. W. Application of fuzzy sets to climatic classification. Agricultural and Forest Meteorology, Amsterdam, v. 35, n. 1-4, p. 165-185, 1985.

MIELKE, P. W. J; BERRY, K. J. Permutation methods : a distance function approach. New York: Springer, 2007. 439 p.

MINASNY, B.; MCBRATNEY, A. B. FuzME version 3. Sidney: Australian Centre for Precision Agriculture, The University of Sydney, 2002. Disponível em

<http://syd ney.edu.au/agriculture/acpa/software/fuzme.shtml>. Acesso em 7 mar. 2011.

MOLIN, J. P.; CASTRO, C. N. de C. Establishing management zones using soil electrical conductivity and other soil properties by the fuzzy clustering technique. Scientia Agricola, Piracicaba, v. 65, n. 6, p. 567-573, 2008. 
MOLIN, J. P.; MOTOMIYA, A. V. de A.; FRASSON, F. R.; FAULIN, G. D. C.; TOSTA, W. Test procedure for variable rate fertilizer on coffee. Acta Scientiarum Agronomy, Maringá, v. 32, n. 4, p. 569-575, 2010.

MORAL, F. J.; TERRÓN, J. M.; MARQUES DA SILVA, J. R. Delineation of management zones using mobile measurements of soil apparent electrical conductivity and multivariate geostatistical techniques. Soil and Tillage Research, Amsterdam, v. 106, n. 2, p. 335-343, 2010.

MORARI, F.; CASTRIGNANÒ, A.; PAGLIARIN, C. Application of multivariate geostatistics in delineating management zones within a gravelly vineyard using geo-electrical sensors. Computers and Electronics in Agriculture, New York, v. 68, n. 1, p. 97-107, 2009.

ODEH, I. O. A.; MCBRATNEY, A. B.; CHITTLEBOROUGH, D. J. Soil pattern recognition with fuzzy c-means: application to classification and soil-landform interrelationship. Soil Science

Society America Journal, Madison, v. 56, p. 505-516, 1992.

PIMENTEL GOMES, F. P.; GARCIA, C. H. Estatística aplicada a experimentos agronômicos e florestais. Piracicaba: FEALQ, 2002. 305 p.

PING, J. L.; DOBERMANN, A. Creating spatially contiguous yield classes for site-specific management. Agronomy Journal, v.95, p.121-113, 2003.

RODRIGUES JUNIOR, F. A.; VIEIRA, L. B.; QUEIROZ, D. M. de; SANTOS, N. T. Geração de zonas de manejo para cafeicultura empregando-se sensor SPAD e análise foliar. Revista Brasileira de Engenharia Agrícola e Ambiental, Campina Grande, v. 15, n. 8, p. 778-787, 2011.

ROUDIER, P.; TISSEYRE, B.; POILVE, H.; ROGER, J. M. A technical opportunity index adapted to zone-specific management. Precision Agriculture, Dordrecht, v. 12, n. 1, p. 130-145, 2011.

TOU, J.; GONZALEZ, R. Pattern recognition principles. Reading: Addison-Wesley, 1974. 377 p.

VALENTE, D.S.M.; QUEIROZ, D.M.; PINTO, F.A.C.; S ANTOS, N.T.; S ANTOS, F.L. Definition of management zones in coffee production fields based on apparent soil. Scientia Agricola,

Piracicaba, v. 69, n. 3, p. 173-179, 2012.

VITHARANA, U. W. A.; MEIRVENNE, M. V.; SIMPSON, D.; COCKX, L.; BAERDEMAEKER, J. de. Key soil and topographic properties to delineate potential management classes for precision agriculture in the European loess area. Geoderma, Amsterdam, v. 143, n. 1-2, p. 206-215, 2008.

WOLLENHAUPT, N. C.; WOLKONSKI, R. P.; CLAYTON M. K. Mapping soil test phosphorus and potassium for variable-rate fertilizer applications. Journal of Production Agriculture, Madison, v. 7, n. 4, p. 441-448, 1994.

XIANG, L.; YU-CHUN, P.; ZHONG-QIANG, G.; CHUN-JIANG, Z. Delineation and Scale Effect of Precision Agriculture Management Zones Using Yield Monitor Data Over Four Years.

Agricultural Sciences In China, Maryland, v. 6, n. 2, p. 180-188, fev. 2007.

XIN-ZHONG, W.; GUO-SHUN, L.; HONG-CHAO, H.; ZHEN-HAI, W.; QING-HUA, L.; XUFENG, L.; WEI-HONG, H.; YAN-TAO, L. Determination of management zones for a tobacco field based on soil fertility. Computers and Electronics in Agriculture, New York, v. 65, n. 2, p. 168$175,2009$.

ZUCOLOTO, M.; LIMA, J. S. S; COELHO, R. I.; QUARTEZANI, W. Z. Variabilidade espacial das frações granulométricas e da produção de bananeira 'Prata Anã'. Idesia, Arica, v. 29, n. 2, p. 47$52,2011$. 